\title{
STUDY OF BIO-ETHANOL PREPARATION FROM ARENGA PALM SUGAR
}

\author{
Hanny F. Sangian ${ }^{1)}$, Seni Tongkukut ${ }^{1)}$ \\ 1) Deptartment of Physics, University of Sam Ratulangi Manado 95115
}

\begin{abstract}
This study purposes to prepare bio ethanol by using two column reflux distillation. In North Sulawesi has been known a very potential crop for yielding bio ethanol, is palm crop. Palm crops more productive than cane in yielding sugar and bio fuel per hectare. Its productivity about 4-8 times compared to cane, and its sugar rendement $14 \%$, while cane only $7 \%$. Based on this research were obtained the tapping process should be conducted by unique sequential steps in order to reach $\mathrm{pH} 8$ and brix $12-14 \%$ of juice. By using of saccharomyzes ceraviseze and traditional technology was obtained fermented liquor with rate $35-42 \%$. Prior to preparation two column reflux distillation apparatus had been designed and constructed successfully to prepare bio ethanol. Testing of bio ethanol preparation also is carried out by using two column distillation methods. Bio ethanol preparation used beer fermented from palm juice. High purity bio ethanol has been prepared successfully so far at Renewable Energy Lab University of Sam Ratulangi Manado. Surprised results were found that the ethanol purity varied from $95 \%$ to $99 \%$. The highest purity is at of $99 \%$ by maintaining the column temperature of $78.5^{\circ} \mathrm{C}$ while purity of $95 \%$ is of $78.7^{\circ} \mathrm{C}$
\end{abstract}

Keywords: ethanol two column reflux distillation, fermentation, palm juice

\section{STUDI PEMBUATAN BIOETANOL DARI NIRA AREN}

\begin{abstract}
ABSTRAK
Studi ini bermaksud untuk membuat bio ethanol dengan menggunakan teknik destilasi dua kolom. Di Sulawesi Utara Indonesia telah dikenal tumbuhan yang dapat menghasilkan bio etanol yang disebut aren (arenga pinnata). Tumbuahan ini adalah lebih produktif menhasilkan gula dari pada tebu dilihat dari jumlah per hektarnya. Produktivitasnya adalah sekitar 4-8 kali dari pada tebu dengan rendemen gulanya sekitar $14 \%$, sementara tebu hanya $7 \%$. Berdasarkan hasil studi diperoleh bahwa proses penyadapan harus dilakukan dengan tahapan yang unik pada $\mathrm{pH} 8$ dan brix 12-14\%. Dengan menggunakan saccharomyzes ceraviseze dan teknologi tradisional diperoleh beer dengan kadar 35-42\%. Sebelum pembuatan etanol, didahului dengan desain dan konstruksi peralatan destilasi refluks dua kolom. Dari hasil pembuatan didapat hasil yang sangat baik. Bio etanol kemurnian tinggi telah diperoleh dengan sukses selam studi ini. Hasil mengejutkan diperoleh bahwa kemurnian etanol bervariasi dari 95\% sampai 99\%. Kemurnian tertinggi adalah pada 99\%dengan mempertahankan temperatur kolom $78.5^{\circ} \mathrm{C}$ sementara kemurnian $95 \%$ adalah pada $78.7^{\circ} \mathrm{C}$.
\end{abstract}

Kata kunci: fermentasi, air nira, etanol, destilasi dua kolom.

\section{INTRODUCTION}

Alcohol is chemicals produced from crop material consist of extract, such as cassava, corn and sago which is usually referred as by bio ethanol. These crops are the ordinary food crop planted by almost all Indonesia people. In the Province of North Sulawesi exists a very potential crop and have some excellence compared to another crop in yielding ethanol, is palm crop.

Palm Crop (Arenga Pinnata) grows in some area of Indonesia and with other palm crop group are the important crop in tropical region (Harjadi, 1986). The area of swampy forest which is at most in region Sumatra (South Sumatra, West and East and Aceh), Java (West Java and Middle), Sulawesi 
(North Sulawesi, Middle, South and East), Maluku (Seram), North Maluku (Halmahera and Bacan) and Papua.

In West Java the crop was recognized by lirang or nanggung, in mid Java recognized by taren or kawung, while in Sumatra recognized by anau, nau, hanau, peluluk, bergat or mergat. This crop has an adaptation ability to height place from sea level can reach 0 till 1400 metre (Akuba, 2004).

Its amount surely has not yet been known but believed that the potency of palm in Indonesia is huge which spread from coastal area to mountain. Based on survey data from Hall of Research of Coconut and Palma said the total of productive palm population in North Sulawesi by 2007 reach 2 million trees. Each palm tree yields the palm juice (called "nira") $20-25$ litre per day. Total production of palm juice is of 40.000 50.000 kiloliter per day. If assumed the average of production per day 45.000 kiloliter and if its two third processed become ethanol with the comparison 6:1, hence can be produced 5.000 kilolitres per day or equal 60.000 kilolitres per year. If using the assumption of spreading area by research of Harjadi (1996) there are 13 areas in Indonesia having swampy forest at most palm crop. If each area have the population 2 million trees, meaning Indonesia have the potency in production of palm bio ethanol \pm 780.000 kilolitre per year. Palm juice, beside of changeable to bio ethanol as a renewable energy, also can yields the palm sugar. Palm tree can also produce the rib, fibre of palm tree, its leaf for the house roof, and its wood with the high quality, a delicious food (called kolang-kaling). Now is newly realized that the palm crop have the remarkable potencies from economic facet, earnings generalization, and poorness reducing, and environment preservation (Anil K. Rajvanshi, 2003).

Economic facet, by the certain process will yield palm juice as the main material in palm sugar and ethanol production. From facet of earnings generalization, palm crops were laboured by small farmers and most have not cultivated yet (wild growing) in forest about settlement. In consequence, the mentioned economic products were exploited by people have low income hence palm crops can be made as a rural unemployment and poorness protection program. By the environment preservation facet, palm crops grow together with others trees. Therefore, palm tree able to create the good ecology so that created by a biological balance. Despitefully, because of growing together with other tree, palm trees can become the good water resistant and relatively difficult to be burned. The interesting thing, palm crop not requires the fertilization to grow, is not attacked by pest and disease obliging peaceful pesticide use so that save for environment. Even we can say its product is organic. Palm crops can grow on marginal farm, on mountainside or hilly with other crops. While cane has to be planted on fertility farm and flat land so that in farm use compete with the other crops like paddy and corn (Mendez and Michael, 2004).

From productivity side, palm crops much more productive from cane in yielding sugar and bio fuel per set of wide range. Its productivity can 4-8 times compared to cane, and its sugar content $14 \%$, while cane only $7 \%$.

The development problem is most people have less of knowledge about palm crop compared to palm coconut, coconut, and cane. The knowledge is about:

- The crop selection in having high productivity and its cultivation.

- The effective and efficient harvest process.

- The transportation from palm farm to factory in order not to destroy.

- The modern result processing system.

- The organization and management. Start from farmer organization, distribution organization and also palm agro business management system.

The Production of bio ethanol feedstock from palm juice is conducted by the process of palm juice fermentation and enhancing yeast so that yielded bio ethanol with the certain concentration. In order to reach the certain grade of ethanol, hence the beer as a fermentation result still have to purified by using column distillation.

Consider to multifarious bio ethanol using, so that grade ethanol exploited have to differ as according to its use. For the bio ethanol of having grade 90-96,5 percent volume can be used for industry purposes, while bio ethanol having grade 96-99,5 percent volume can be used as mixture for alcohol drink and substance of pharmacy industry, different with the level of grade 
ethanol exploited as fuel should have the grade 99,5-100 percent volume and anhydrous (Polnaja, M, 2000).

\section{Research Objective}

This research was conducted with objectives to: a) Understand the efficient and effective process of palm juice tapping; b) Design and construct of two column reflux distillation apparatus; c) Obtain the bio ethanol $>96 \%$ volume by using palm juice feedstock.

\section{THEORETICAL REVIEW}

\section{A. The Fermentation}

The process of alcohol making depended on its feedstock. The sugary feedstock usually needs a little initial process. Different to extraction/essence substances or cellulose should be hydrolyze first in order to change the complex sugar become the simple sugar which can be fermented.

The following figure depicting comparison of production bio ethanol process feedstock from cassava, corn or seeds with feedstock from palm juice.

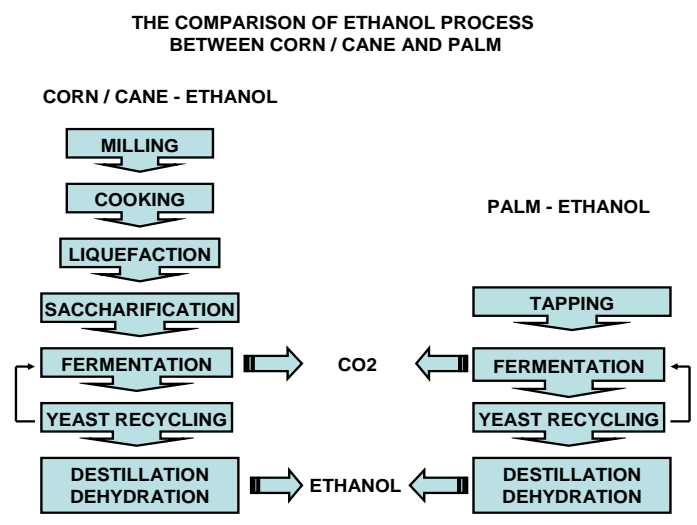

Figure 1. the Comparison of Ethanol Processing

Fermentation is one of several methods in alcohol making, biochemical activities of micro organism are usually used under anaerobic condition. During fermentation, feedstock changed to alcohol. Sucrose content of feedstock is broken down to glucose, and glucose fermentation produces alcohol. Basically, fermented alcohol comes from glucose conversion. The yeast Saccharomyces serevisiae is usually used as supporting microbes for fermentation. The alcohol fermentation is started with glycolysis process. The glucose compounds are broken down to pyruvic acid via EmbdenMeyerhof pathways. The pyruvic acid is then converted to acetaldehyde and carbon dioxide by microbes. Finally, this acetaldehyde was converted to ethanol.

\section{$\mathrm{C} 6 \mathrm{H} 12 \mathrm{O} 6 \longrightarrow 2 \mathrm{CH} 3 \mathrm{COCOOH} \longrightarrow 2 \mathrm{CHCHO}+$ $\mathrm{CO} 2$ \\ Glucose

$$
\text { Pyruvic acid }
$$

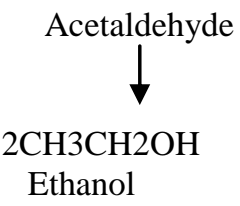

Figure 2. Reaction sequences for the alcohol fermentation

The production process of bio ethanol feedstock from palm juice only need a little of initial treatment are palm juice cooking then run the fermentation process by using of saccharomyzes ceraviseze yeast, having perfect growth at above $30^{\circ} \mathrm{C}$ and $\mathrm{pH}$ 4,8. The yeast has function to change the glucose become the alcohol and $\mathrm{CO} 2$. The using of saccharomyzes ceraviseze yeast is considered based on the ability fast multiply; having live endurance to high concentration alcohol; resistance to high temperature; having the stable and fast adaptation with the media fermented.

To obtain the optimal result in yeast cultivation, hence the environment condition should be reengineered by considering some factors in the following:

a. Nutrition. In its activity yeast need the nutrition addition for the growth and cultivation, for example, Element $\mathrm{C}$ : there is in carbohydrate; Element $\mathrm{N}$ : with the manure addition contains of ZA, Urea, Ammonia and Peptone; Element P: addition manure the phosphate from NPK, TSP, and other; mineral and vitamins.

b. Acidity $(\mathrm{pH})$. For the fermentation, yeast needs the sour atmosphere media that is between $\mathrm{pH} 4,8-5,0$. Arrangement $\mathrm{pH}$ done by a sulphate acid addition if its substrate alkalis or natrium bicarbonate if its substrate sour.

c. Temperature. The optimum temperature for the cultivation is $28-30^{\circ} \mathrm{C}$. When the 
fermenting, the temperature increase, hence to prevent fermentation temperature not goes up, need cooling down so that temperature remain to range $28^{0}-30^{\circ} \mathrm{C}$.

d. Air. Although fermentation take place by anaerobe (without air), but seed process before fermentation, exactly air needed (aerobe) for the cultivation.

Ethanol yielded by fermentation process require to be improved its quality by cleaning it from chemical elements which not needed, for example usually still contain the $\mathrm{CO} 2$, generated from distorting glucose become the ethanol and aldehyde which require to be cleaned.

The ethanol rate was yielded from fermentation process, usually only reach $8-$ $10 \%$. This Ethanol is referred as "beer". In order to obtain the ethanol with rate $95 \%$ needed another process, is distillation process. While to obtain the bio ethanol with the purity greater than $99.5 \%$ (fuel based ethanol), has problem in hydrogen dissociation, therefore to get the fuel based ethanol executed furthermore purification by Azeotropic distillation.

\section{B. The Distillation}

The objective of distillation is the separation of the alcohol from the other ingredients in the beer, mostly water. In making fuel alcohol it is necessary to get all of the alcohol and water separated if the alcohol is going to be mixed with gasoline, and most of the alcohol and water separated if the alcohol is going to be burned in a converted engine. As will be seen, the purer the alcohol, the harder it is to make.

The separation of the alcohol and water by distillation is made possible by the fact that alcohol boils at about $78.5^{\circ} \mathrm{C}$ and water $100^{\circ} \mathrm{C}$. When the mixture of water and alcohol is boiled, vapours with a greater concentration of alcohol will be formed and liquid with a lesser concentration of alcohol will remain behind. However, because water and alcohol do not form what is called an "ideal" mixture, the separation cannot be done in one clean step.

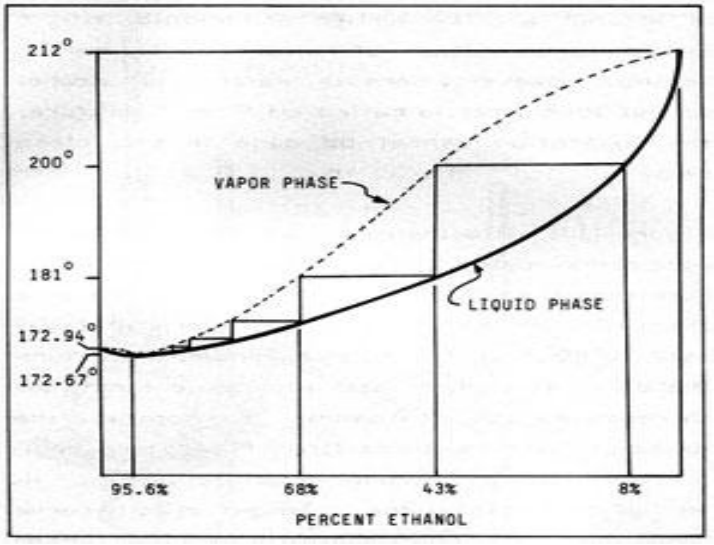

Figure 3. The composition of liquid phase of water/ethanol mixtures

As shown by figure above, the heavy solid curve represents the composition of the liquid phase of water/ethanol mixtures plotted against the temperature at which the mixture boils. The dotted curve represents the vapour phase. Using the apparatus illustrated, and starting with a concentration of $8 \%$ alcohol in water, the liquid will boil at about 200 degrees F. Reading across, the vapours will contain about $43 \%$ alcohol. Clearly, for fuel purposes, a purer product is needed. To this end, we must redistill the condensed vapours from the first distillation which contain $43 \%$ alcohol and 57\% water. This mixture will boil at about 181 degrees $F$. and the vapours will contain about $68 \%$ alcohol. Each time the condensed vapours are redistilled, they will be slightly purer, but many separate distillations are needed to produce relatively pure alcohol. Fortunately, a type of distillation apparatus, called a reflux (or rectifying column), in effect, performs simultaneous distillations and will be described later.

However, with the equipment described, no matter how elaborate, the purest alcohol that can be produced is $95.6 \%$. The remaining $4.4 \%$ water is impossible to remove because at this ratio, water and alcohol form a constant boiling mixture (called an "azeotrope") which boiling point is a fraction of a degree below that of pure alcohol, and separation by ordinary distillation is impossible. 


\section{RESEARCH RESULT}

\section{A. Process of Palm Juice Tapping}

1. The tapping process done to palm blossom which ready for tapped is usually marked by many insects (a kind of small wasp) gang flew around the palm blossom.

2. To reach the bloom palm blossom, palm taper has to reach it by climb using the bamboo bar as high as $\pm 15 \mathrm{~m}$. The bamboo is leaned on palm tree, angular shape 50 degree. The palm taper right and left foot thumb step on and tread each hole on bamboo joint.

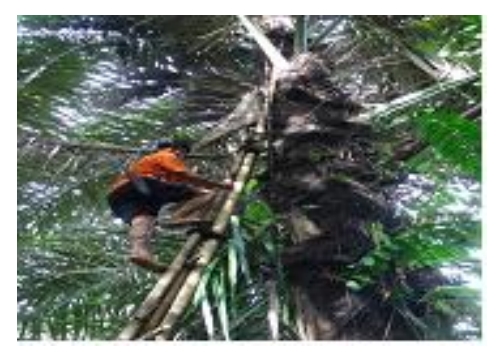

Fig. 4 the bamboo climbing

3. After reaching for tree, taper will sit on one of frond and start to knock the fruit stalk using a wood stick as a mean to open the handle pores. The knocking takes 1015 minutes. The knocking frequency is usually done 4 days once during a month.

4. The next activity is clean up the palm stalk from its fruit till remained the cleaned palm stalk as long as $36-43 \mathrm{~cm}$. This stalk will be sliced flimsy $( \pm 2 \mathrm{~mm})$ vertically or obliquely, according to its requirement (for what purpose palm juice was tapped, sugar or ethanol making). The different way of slicing will determine the yielded type of palm juice. Slice obliquely will yield the palm juice for sugar making (pH 7 and brix 12-14\%) while vertically slicing will yield the palm juice for traditional alcohol making (called "cap tikus") by pH 4 and brix $5-7 \%$.

5. The secretion of palm juice is accommodated in bamboo tube. The other way, palm juice secretion can be flowed through by plastic hose into jerry can which placed on the ground near tree bar. From a palm stalk obtains 20 - 25 litre of palm juice during 24 hours.

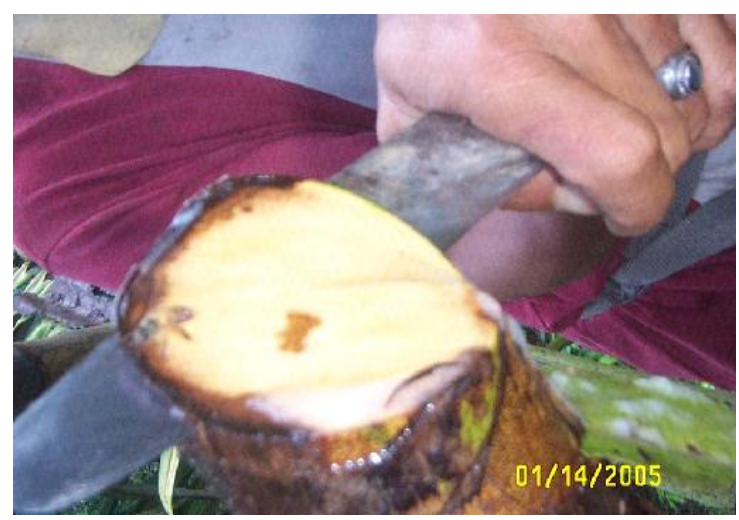

Fig. 5. the obliquely slicing of palm stalk

6. Every day, the tapping is renewed by making a thin slice to the palm stalk with interval slice $\pm 2 \mathrm{~mm}$. Therefore short fruit stalk in process of time and usually will used up after 8 months tapped. The tapping was done for $2-3$ stalks per tree. For the next 4 months period the palm will sprout again and the routine activities will happen again (Sangian, H.F, Sondakh, 2008).

\section{B. The Process of Palm Juice Alcoholisation}

\section{The initial treatment}

This research uses 3 samples of palm juice with different composition as shown on table below:

Table 1. The Palm Juice Composition (before fermentation)

\begin{tabular}{|c|c|c|c|}
\hline Analysis & $\begin{array}{c}\text { Sample } \\
\mathbf{1}\end{array}$ & $\begin{array}{c}\text { Sample } \\
\mathbf{2}\end{array}$ & $\begin{array}{c}\text { Sample } \\
\mathbf{3}\end{array}$ \\
\hline Glucose (\%) & 27.25 & 27.30 & 27.19 \\
\hline $\begin{array}{c}\text { Total sugar } \\
(\%)\end{array}$ & 58.50 & 58.00 & 58.90 \\
\hline $\begin{array}{c}\text { Sucrose (\%) } \\
\text { Ash content } \\
(\%)\end{array}$ & 0.50 .12 & 30.15 & 30.17 \\
\hline $\mathrm{pH}$ & 4.06 & 4.11 & 4.08 \\
\hline
\end{tabular}

The initial process is intended to obtain the optimal condition for yeast growth, in consequence which require to be accommodated in this processing are the $\mathrm{pH}$, concentration and nutrition usage. Palm juice used for the making of ethanol is from slicing result obliquely (pH 7 and brix $12-14 \%$ ) was intended for juice reengineering, utilize to 
reach the optimal condition for seeding and fermentation (seeding $\mathrm{pH} 4$ and brix 13\% while fermentation $\mathrm{pH} 4$ and brix 22\%). The way is by to warm-up palm juice at temperature $70^{\circ} \mathrm{C}$ during 15 minute, and then cooled it down during 1 hour till reach the temperature $30^{\circ} \mathrm{C}$. By this way, beside optimal condition can be reached, the juice can also free from the other microbe contamination. The sterile juice has ready for the seeding or fermentation. By this treatment was obtained the following results:

- Sugar rate (brix) of treatment juice is $12,6 \%$ for the seed and $24,8 \%$ for the fermentation,

- $\mathrm{PH}$ arrangement was conducted by the addition of $\mathrm{H}_{2} \mathrm{SO}_{4}$ as much $1,51 \times 10^{-3} \mathrm{~kg}$ per 1 litre of juice. This treatment yield the $\mathrm{pH}: 4-5$,

- For nutrition feeding was used by NPK with ratio $1: 1,61 \times 10^{-3} \mathrm{~L} / \mathrm{kg}$ and urea with ratio $1: 4,55 \times 10^{-3} \mathrm{~L} / \mathrm{kg}$.

\section{Yeast Seeding}

This process intended to multiply the yeast cells so that become more before used in alcohol fermentation. Yeast was used to the fermentation is Saccharomyzes ceraviseze. It's using not directly, but must be done step by step with a view to adaptation with the medium. It started in laboratory scale, and then developed furthermore in tank of seeding in a condition aerobe and temperature $28^{0}-30^{0} \mathrm{C}$ during the incubation.

\section{Fermentation}

The fermentation conducted in fermentation tank, with the concentration brix $22-24 \%$ and $\mathrm{pH} 4-5$. To alcohol fermentation required anaerobe condition so that the yeast cells ferment and change the sugary palm juice become the alcohol. This process is needed a refrigeration to keep the temperature stable at $\pm 30^{\circ} \mathrm{C}$ during fermentation running (48 hours). From this research was obtained the average of 1 litre of palm juice with the special treatment contain $53-57 \%$ sugar which fermented.

The bio ethanol yielded from fermentation process still contain the gas of $\mathrm{CO}_{2}$, so that to obtain the bio ethanol with good quality, it still have to be cleared from the gas.
By the end of fermentation, yielded ferment liquor, usually is called "beer" with the alcohol rate range from $12-14 \%$ volume and have the purity about $35-42 \%$. By using of special treatment was intended to reach the purity up to $95 \%$, hence the bio ethanol still has to through by distillation process.

\section{The Distillation Process Using The Two Column Reflux Distillation Apparatus}

A laboratory scale reflux distillation had been installed. The two column reflux distillation consists merely of a metal tube filled with packing material. The purpose of the packing is to provide as large an internal surface area as possible.

As the vapours from the still pot ascend through the column, they condense on the packing material and drip downward. Additional ascending vapours contact the descending liquid (called "reflux") and revaporize it. Thus, as the vapours slowly work their way up the column, they become richer and richer in alcohol until, when they reach the top, they are relatively pure. Meanwhile, the descending liquid is stripped of its alcohol. The overall effect is that many "distillations" are performed simultaneously and the liquid in the still pot is stripped of its alcohol in one continuous operation. Reflux columns can be constructed to operate on either a batch or continuous basis (Sangian, 2006).

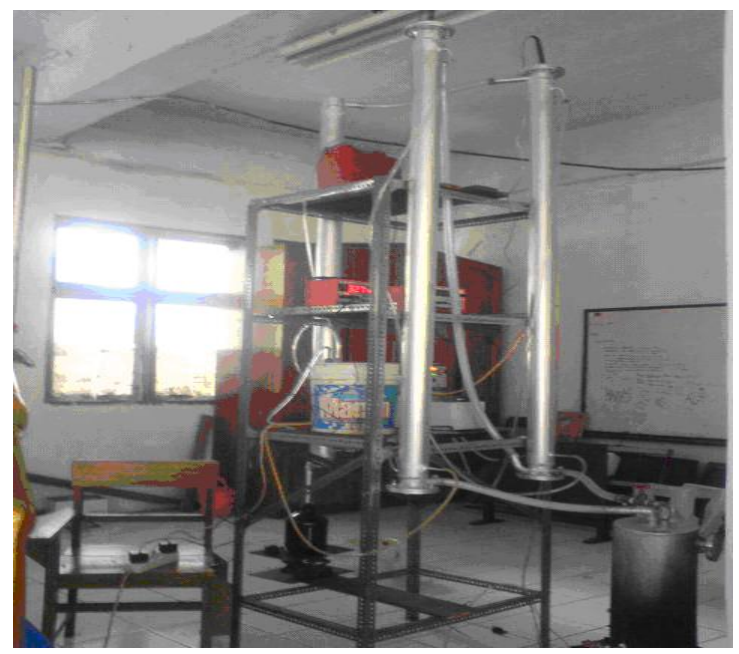

Fig. 6. Two Column Reflux Distillation Apparatus 
Two column reflux distillation apparatus is designed and constructed which consists of column distillatory, boiler, condenser, cool water inlet, warm water outlet, digital thermometer, electronic water circulator, kerosene stove, packing materials and water pump. Dimension of components are column length of $200 \mathrm{~cm}$, column diameter of 6 inches, length of condenser by $200 \mathrm{~cm}$, boiler volume of $12 \mathrm{~L}$. The specifications are digital thermometer of $\mathrm{LH}$ 666198 with thermocouple $\mathrm{NiCr}-\mathrm{Ni}$ (-50 to $+1200^{\circ} \mathrm{C}$ ), water electronic circulator of HAAKE L Fissons DIN 12879 Klasse 1W, water pump of LH $57922(8 \ldots 20 \mathrm{~V})$, power supply of LH 59109, and packing materials of activated carbon and kerosene stove of HOOK. The two column reflux distillation apparatus is showed in figure below.

A batch operation still is simply a reflux rectifying column attached to a suitable boiler. The boiler is loaded with arenga liquor drink, the bio ethanol was distilled out of the liquor, and then the still is shut down while the stillage is emptied from the boiler and a fresh batch of liquor run in.

The column is simply a length of pipe filled with a packing material to provide a large internal surface area. Aside from the pipe to hold the packing, some sort of screen or retainer is put at the base of the column to keep the packing from falling into the boiler. The thermometer at the top of the column is to check the temperature of vapours going to the condenser. A 1.5 inch diameter column of this design is about 1.5 long. It would be capable of producing about 1 litre per hour, depending on the initial concentration and volume of the liquor.

Successful operation of the simple reflux column depends on careful regulation of the amount of vapour going to the column. In the testing still, it is often difficult to control the amount of vapour produced by boilers that are fuelled by kerosene stove. The reflux control was added to the column and used to regulate temperatures at the still head with a great degree of accuracy. The reflux control unit is simply coaxial pipe in outer of the column used to control the amount of reflux.

Top of the column is connected to a condenser to cool the vapours back into the liquid form. The condenser is constructed coaxial pipe where the inner pipe is channel of and outer pipe is a channel of cooler water. Here water is used as the heat exchange medium. Also, if the vapours going into the condenser are impeded in any great degree, pressure could build up inside the column and boiler. Therefore, the diameter of tubing in a condenser for a 1.5 -inch column is $1 / 2$ inch tubing.

The boiler volume is $12 \mathrm{~L}$ and can be adapted for many purposes. The boiler was designed allow maximum surface area for heating and the production of vapour. To increase efficient of boiler be made from a hot water heater. Hot water heaters used kerosene stove.

In operation, the boiler or still pot was filled to no more than the 3/4 level with the liquor to be distilled. As the liquid begun to boil, vapours rose in the column. After a while, the column would come up to temperature, and equilibrium would be established. For a normal liquor concentration of about $30 \%$, the initial temperature of the vapours in the still pot was about $840 \mathrm{o}$, while the palm juice sap of $5 \%$ was $950 \mathrm{oC}$. The vapours was cooled they rose in the column and, at the top; they should between 76 and $780 \mathrm{C}$ which is the approximate boiling point of the water/bio ethanol.

If the boiler was supplying more vapour than the column can handle, the temperature at the still head would rise above $78 \mathrm{oC}$ and the proof of the product going to the condenser would be reduced. Conversely, if the boiler was not producing enough vapour the temperature at the still head would be low and no vapours would be going to the condenser. On our still with reflux control, the boiler was adjusted to produce an excess amount of vapour. 
After the column has stabilized, the product of bio ethanol flows to the high proof bottle. When distillation begun, certain low boiling vapours came over, and a small amount of liquid came out of the condenser not ethanol. This liquid was composed of substances in the liquor that have a lower boiling point than ethanol.

As the distillation progresses, the vapours in the still pot would contain a greater and greater percentage of water and a correspondingly lesser proportion of bio ethanol. The still pot vapour temperature would rise. Eventually, a point would reach where there was too little bio ethanol in the vapour for the column to achieve effective separation. The temperature at the still head was risen slightly and the proof of the product would be lower. At this point, it is best to collect the product coming from the condenser in the low proof bottle.

The distillation was continued until the temperature at the still head equals the temperature of the vapours in the boiler, which would be near 98$100 \mathrm{oC}$ depending on altitude, atmospheric pressure, and the amount of dissolved material in the liquor.

When all the bio ethanol has been removed from the liquor, as indicated by boiler and still head vapour temperatures, the distillation was complete. The liquor, now called "stillage", was drained from the boiler, and a fresh charge of liquor run in. The low proof "tail" from the previous run was added to the fresh charge of liquor, and the still was ready for another run.

The distillation is continued until the temperature at the still head equals the temperature of the vapors in the boiler, which will be near $98-100 \mathrm{oC}$ depending on altitude, atmospheric pressure, and the amount of dissolved material in the beer. When all the bio ethanol has been removed from the beer, as indicated by boiler and still head vapor temperatures, the distillation is complete. The beer, now called "stillage", is drained from the boiler, and a fresh charge of beer run in. The low proof "tail" from the previous run is added to the fresh charge of beer, and the still is ready for another run.

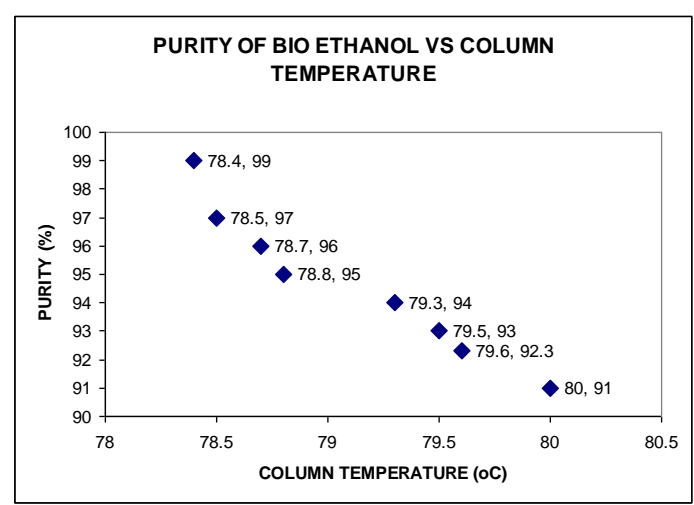

Fig. 7. Purity of bio ethanol versus column temperature

Figure 5 above shows the summary results have been achieved for 10 month research in laboratory. Actually, there are hundreds of data obtained in this study; because of the limited space of page paper the author is just summarized.

Of the testing of arenga bio ethanol preparation discovers that the proof of product varies from $95 \%$ to $99 \%$. The highest of the proof of bio ethanol is of $99 \%$ by maintaining of column temperature at $78.5 \mathrm{oC}$, while the proof of $95 \%$ at $78.7 \mathrm{oC}$. The flow rate of product also varies from 0.1 to $0.2 \mathrm{~mL}$ per second with beer volume of $12 \mathrm{~L}$.

In figure 7 shows that the highest purity of the bio ethanol of $99 \%$ by keeping column temperature at $78.4 \mathrm{oC}$, while purity of $91 \%$ at of $80 \mathrm{oC}$. If the column temperature is increased the purity of the bio ethanol will decreased. It caused by more water molecules will vaporize then flow to the condenser. When the column temperature passes $79 \mathrm{oC}$ the purity of bio ethanol will drop below $95 \%$. In our measurement that the column temperature $80 \mathrm{oC}$ would produce the purity of product around $91 \%$ and $78.5-79 \mathrm{oC}$ was of $95 \%$, and $96 \%$. In preparation of the bio ethanol by using two column reflux distillation technique, 
the art of preparation is to set column temperature accurately.

\section{CONCLUSION}

1. In the tapping process, the palm stalk should be sliced obliquely in order to obtain palm juice with $\mathrm{pH} 8$ and sugar concentration (brix) $12-14 \%$. By this way palm juice is possible to reengineer, in reaching the optimal condition for seeding and fermentation.

2. By the juice reengineering was obtained results :

- Sugar rate (brix) of treatment juice is $12,6 \%$ for the seed and $24,8 \%$ for the fermentation,

- $\mathrm{PH}$ arrangement was conducted by the addition of $\mathrm{H}_{2} \mathrm{SO}_{4}$ as much $1,51 \times 10^{-3} \mathrm{~kg}$ per 1 litre of juice. This treatment yield the $\mathrm{pH}: 4-5$,

- For nutrition feeding was used by NPK with ratio $1: 1,61 \times 10^{-3} \mathrm{~L} / \mathrm{kg}$ and urea with ratio $1: 4,55 \times 10^{-3} \mathrm{~L} / \mathrm{kg}$.

3. By using of saccharomyzes ceraviseze yeast was obtained ferment liquor (usually called "beer") with alcohol rate range from $12 \%-14 \%$ volume and purity about $35-42 \%$.

4. Two column reflux distillation apparatus had been designed and constructed successfully to prepare bio ethanol continued by testing of bio ethanol preparation.

5. Surprised results were found that the ethanol purity varied from $95 \%$ to $99 \%$. The highest purity is at of $99 \%$ by maintaining the column temperature of $78.5^{\circ} \mathrm{C}$ while purity of $95 \%$ is of $78.7^{\circ} \mathrm{C}$.

6. The flow rate of bio ethanol also is varied from $0.1 \mathrm{~mL}$ to $0.2 \mathrm{~mL}$ per second depended on both column temperature and heat supplied in boiler. If the column temperature was increased the purity of the bio ethanol will decreased caused by more water molecules will vaporize then flow to the condenser. When the column temperature was above of $79^{\circ} \mathrm{C}$ the purity of bio ethanol will drop below 95\%. In our measurement that the column temperature was range of $78.5-79^{\circ} \mathrm{C}$ the purity was of $95 \%$, and $96 \%$.

\section{REFERENCES}

Akuba, Rustamrin. 2004. Profil Aren. Makalah Presentasi Pada Seminar Nasional "Pengembangan Tanaman Aren". 9 Juni 2004. Tondano.

Anil K. Rajvanshi.2003. R\&D strategy for lighting and cooking energy for rural households. Current Science Vol. 85 No. 4.

Douglas, G.T. and V. Eidman. 2003. Factor Associated with Success of Fuel Ethanol Producers. Staff Paper. P0307.

Lioyd. A.M. Chemistry In Engineering. Pretince Hall, INC, N.J.

Mendez and Michael. 2004. Fuel EthanolProcess Development. Journal of Agricultural Research service.

Polnaja, M. 2000. Potensi aren sebagai tanaman konservasi dan ekonomi dalam pengusahaan hutan rakyat. Warta Penelitian dan Pengembangan Industri Vol 5 No.4.

Sangian, H.F., D.S.I. Sondakh. 2007. Developing of Arenga Pinnata Ethanol Fuel for Alternative Energy Source in The Coming Years. International Seminar on ICT Application in Agroindustry, Marine and Tourism.

Sangian, H.F. 2006. Arenga Pinnata Ethanol Fuel For Alternative Energy Source for This Age. Science Journal Vol 6 No 1.

Sangian, H.F, D.S.I. Sondakh. 2008. Bio Ethanol From Palm Juice. International Indonesia Student Meeting. Delft Holland. 